Article

A Study of Behavioural Aspects of People at Journal of Development Economics and Home under Lockdown for Corona Management Research Studies (JDMS), A Peer Reviewed Open Access International Journal ISSN: 25825119 (Online)

Crossref Prefix No: 10.53422 08(09), 1-24, July-September, 2021 @ Center for Development Economic Studies (CDES) Reprints and permissions http://www.cdes.org.in/ http://www.cdes.org.in/journal/

\title{
A Study of Behavioural Aspects of People at Home under Lockdown for Corona
}

\author{
T. Vasantha Kumaran $\mathrm{PhD}$ and O.M.Murali $\mathrm{PhD}$, \\ Geographers and Independent Researchers, Chennai
}

\begin{abstract}
Purpose. The purpose of the paper is to examine behavioural aspects of people who work from home, and also those who are under lockdown for the Coronavirus pandemic. This we make out from a survey of people from different walks of life and concerned with a future they want.
\end{abstract}

Methods and Materials. Essentially, a survey of 210 participants (183 Indians and 27 NRIs abroad), using a custom-designed questionnaire. Responses have been solicited using WhatsApp, on sending the questionnaire in Google Forms. The questionnaire has 35 questions, for collecting information on a variety of aspects, but particularly about their fears, confidences, worries, mental stress and trauma and how they have coped with their situation.

Results and Discussion. Two hundred and ten people of all ages, 21-66 years, with about 69 per cent men and about 31 per cent rest women, and about 87 per cent Indians and about 13 per cent NRIs abroad, relate their positive as well as negative experiences. Professionals of 46 different sectors of the economy, with four-fifths of them working from home, they (90.9 per cent of them) speak of home as a safe zone. Yet, with three-fifths of them clearly understanding the seriousness of the situation and the pandemic crisis, about 57 per cent of them disturbed by the pandemic, they are burdened by work, feeling lonely (34.4 per cent) under lockdown, their family has people with psychological trauma (26 per cent), elderly with health concerns (in 28.5 per cent of their households), experiencing financial strains and loss (37.5 per cent of them), and yet spending quality time with family and children (62.3 per cent). They have troubled sleeping patterns (47 per cent) but take precautions for overcoming the virus (about 90 per cent), taking immune boosting foods (97 per cent), and taking 
care of the elderly (72 per cent). But the mixed situation at home and outdoors cause considerable behavioural changes and adjustments. This paper speaks of the behavioural aspects of the situation with revealed perceptions of people at home under lockdown.

Keywords: Coronavirus, Pandemic, Fears and Worries, Trauma, Behavioural adjustments.

\section{Introduction}

We live in time of a pandemic that has dramatically, but temporarily, transformed our social world in remarkable and disturbing ways. We are now without the places we have frequented every day and that has given structure to our daily life, what we may for convenience call 'third space' or simply 'public space' (Low and Smart, 2020; Honey-Roses et al. 2020).

People's life is under threat. Everyone is worried. The way we live our lives has changed. At this point, sports takes a back-seat. Saving lives is more important - M. Senthilnathan, Tamil Nadu Cricket Selection Panel Chief.

The Corona Pandemic has been an unexpected Black Swan Event. According to Taleb (2007):

'A black swan is an unpredictable event that is beyond what is normally expected of a situation and has potentially severe consequences. Black swan events are characterized by their extreme rarity, their severe impact, and the widespread insistence they were obvious in hindsight.'

Taleb describes a black swan as an event that (1) is beyond normal expectations; that is, it is so rare that even the possibility that it might occur is unknown; (2) has a catastrophic impact when it does occur; and (3) is explained in hindsight as if it were actually predictable. 


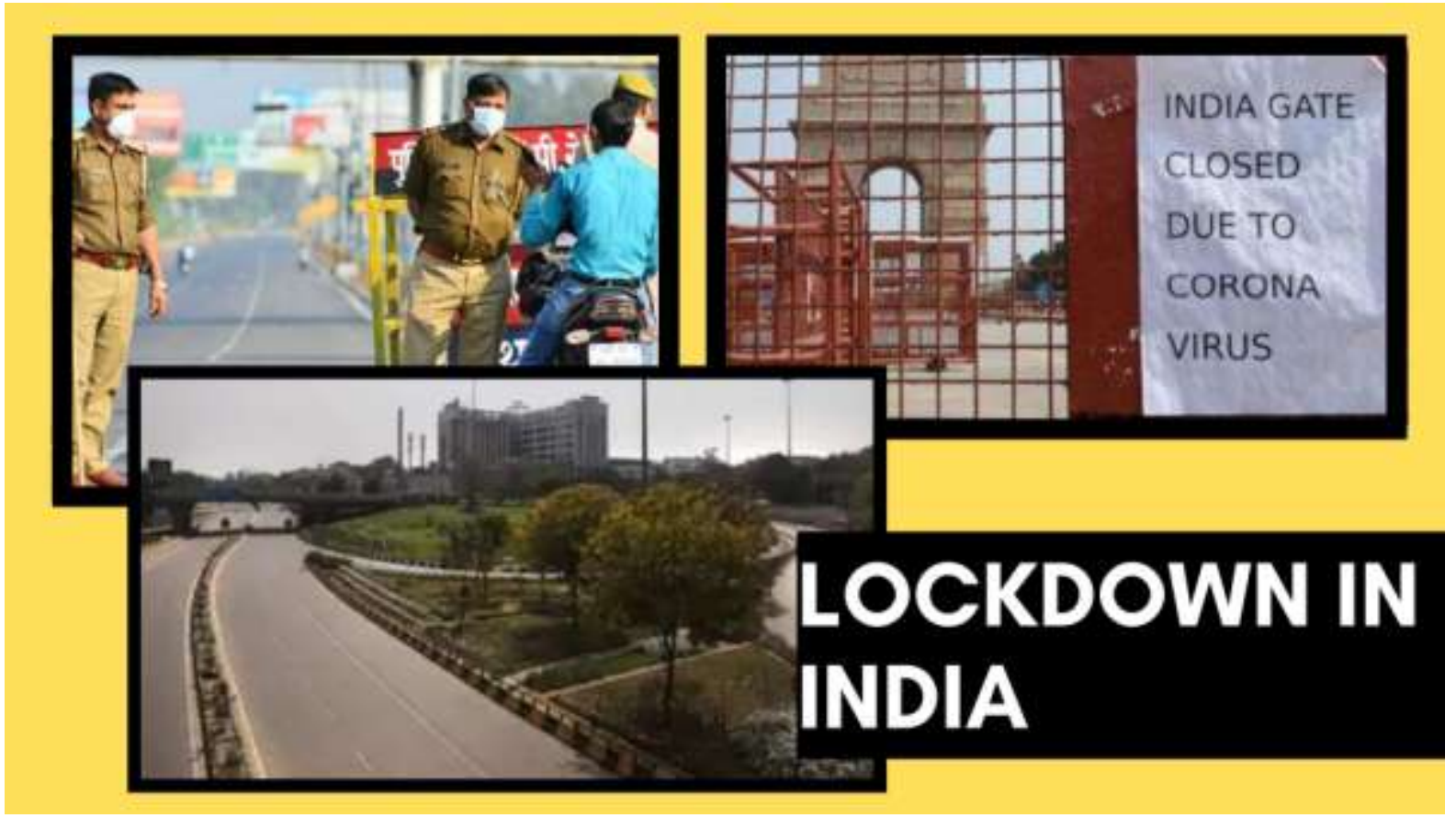

Coronavirus is a true black swan event, sparking corrections across global markets. Odds are that the coronavirus pandemic has doubled to 40 per cent, says Moody's analytics. And the 'black swan coronavirus' not just casts its shadow on the Indian economy but also the global economy, for an estimated 215 countries of the world are under its disastrous spell, now, with no letup in sight except maybe in New Zealand, as of June 09, 2020.

\section{Purpose}

The purpose of this paper is to examine the revealed perceptions and behaviours of people in their struggle during the lockdown for the Coronavirus pandemic. This we do from a survey of people from different walks of life, some working from home and others staying home because of the lockdown. They are all however concerned with the uncertain future they face but do not know what exactly it is.

Several questions need to be answered if one has to understand and also appreciate what is happening. Why is the Coronavirus pandemic more important than all the earlier pandemic? What trouble does it cause that it devastates our economy, the global and the Indian? And why is this happening? Why did we have to shut down the economy to deal with COVID-19 when we did not have to for SARS in 2003, or the H1N1 pandemic in 2009? A new report from the National Bank of Canada points to an answer: the virus appears to be more contagious than previous pandemics, making it easier for COVID-19 to spread. 
The "basic reproduction number" for COVID-19 is nearly 3.5, meaning that the average person who contracts it will infect nearly 3.5 other people. That is, much higher than the typical flu virus that goes around, or any of the viral pandemics over the past century, which had considerably lower reproduction numbers.

\section{Materials and Methods}

Essentially, an online survey has been done using a custom-designed questionnaire. The survey of 210 people, 183 Indian and 27 NRIs living abroad, has been done online. Responses have been solicited using WhatsApp, but by sending the questionnaire in Google Forms (https://drive.google.com/file/d/ 1GAyzXZ2TzHkEFZZ-uh7if9zBgED1-aap/view?usp=drivesdk).

The questionnaire has 35 questions, with just a few seeking demographic details, age, gender, type of family, and professions/occupations. All others are related to perceptions and behaviours as to the nature and impact of lockdown since March 24, 2020, in 4 phases during March-June 2020. The survey has taken nearly a month and the 210 filled-in questionnaires have been received during May 10-June 09, 2020.

For the purpose of this study however only a simple frequency and percentage analysis has been done to get results that could be interpreted simply. Most data being verbal (qualitative), statistical analysis of the data has not been possible at all. In addition to the simple analysis, a randomly select set of people have been contacted for their considered views on the situation, the essence of which is included in the discussion.

\section{How has the Pandemic affected the People of India?}

For a glimpse of what the people under lockdown feel, and also worry about, here are what a few people speak of their struggle and sufferings from the pandemic and the lockdown.

Shivalingappa, who has had a Small Scale Industry (mattresses making) has this to say:

My company has closed its operations since lockdown and has stopped payments of salary to the employees because there is no money with the company. It has been a huge burden to the company, in regard to payments to the Bank overdrafts, loans, interest and rent. The company has run out of money and resources. It is a big impact on similar small scale industry, everywhere. 
Nathan, an Interior Designer, has this to say as to his experience:

Lockdown has resulted in a complete collapse of business for me and I am without a source of income, for now. Family is run with the earlier savings and that is fast depleting. Extended lockdown is very scary in cases of self-employment like mine and I do not know what to do.

Narayanan, a Temple priest by profession, has this to say about his situation:

The primary source of income for me was from the temple services. Lockdown has resulted in the closure of the temple and the visit of the devotees is banned, resulting in a severe constraint to the only source of income I have had. Also, temple-dependent businesses like garland making, nearby shops selling Pooja (worship) items and livelihoods of other dependents have been impacted as well.

Narayan Kumar, an educationist, has this to say about his position today:

Group learning/classroom learning is severely impacted, for the first time I am confined to work from home - Negative aspect of lockdown. However, in online teaching, innovations in learning can be introduced Positive aspect of lockdown. This I am trying to enter into but am finding it hard to break out.

A number of other people, from all walks of life imaginable, have said more or less the same but in so many words, different and painful words.

A 40-year old medical representative (Venkat) has been staying home during the lockdown. His profession demands extensive travel. He has been trying to avoid meeting people in hospitals, although that is what he has been used to do. But hospitals could be the potential infection zone for COVID-19. As such, the lockdown has impacted severely on his economic prospects till now. Medical representatives like him are now feeling the pinch and they want to be back at work and make some money for their livelihoods. Savings if any are drying up.

Likewise, there is also no respite for teaching professionals because they have been taking online classes for students who will be writing public exams. For most school teachers, it has however been a new learningcum-teaching through various online meeting platforms. This has invariably affected teachers (Ms. Sandhya and Ms. Kalaiselvi) and they have experienced stress because they have to wear two hats, the housewife and the online techie. They have had different impacts in this lockdown. 
Ms Sandhya has to extend her working hours from home, including weekends, in case of the absence of some of her colleagues who cannot have access to online platforms. But Ms Kalaiselvi will not get her salary from May till school reopening, which is likely only in September 2020.

Among women workers, servant maids working in households are the most affected. They work in 3 or more households to shore up their incomes. They are normally engaged in cleaning, dishwashing and cooking. Ms Santhi, who works in Anakaputhur in the outskirts of Chennai covers 5 households with an income of around 10,000 rupees a month, has been stopped from work because of the lockdown.

Most servant maids of Chennai have been asked not to come to work in both March and April 2020. This has put all of them in a fix as to make their livelihoods. Ms Santhi finds the going tough for she is not able to meet her home needs and her husband is also out of work. The social support (dole money) and the PDS-distributed essentials are not enough to meet the home needs.

On the positive side, many major industries around Chennai, engaged in component manufacturing, did not stop the salary of their employees though they were not allowed to work during the lockdown.

Thirupathy who works in such an industryas a production manager indicates the considerate nature of the company towards their workforce. Now, production has started with 30-50 per cent capacity which would be ramped up in subsequent phase after following strict social distancing and safety measures in the larger interest of the health of the workers.

We are grateful to the services of IT companies whose innovative technologies have helped us to get things at the click of a button in mobile, laptop or to get the money from ATM. In a way, the work of the IT companies have no doubt helped us to reduce public sufferings by making use of the technology in times of crisis. It is a mixed response from many IT people.

This is the only industry where the work from home option has been extended with minimal impact to the various clients who get the best services out of such initiatives. But salary cut and promotion cycles have been hit for this year for most of the people working with IT.

For a heartrending narrative of everyday travails of people, particularly the migrant workers who are the pillars of the economy, affected by the 
pandemic, lockdown, and suffering an insensitive administration read the articles that have appeared in the Hindu, the national newspaper, by Jebaraj 2020; Lakshman, 2020; Ramani 2020; Sankar 2020; Sinha and Thakur 2020; and Srinivasan 2020.

\section{Revealed Social Behaviours of People: Results of Survey and Discussion}

Gender. More than two-thirds of the respondents (69.4 per cent) are men and the rest (30.6 per cent) are women.

Age. About 32 per cent of the survey participants are in the age group of 21-40 years of age. About 63 per cent of them are in the age group of 41-60 years. The rest of them ( 5 per cent) are in all other age groups: $<20$ years 2.6 per cent and 61-80 years 2.4 per cent.

Family Type of the Survey Participants. Whereas 66.8 per cent of the survey participant-households are single, nuclear families, 33.2 per cent of their families are joint households. Of course, some men who were abroad stayed alone and single while away from India.

Professions / Occupations of Survey Participants. The survey participants are mostly professionals in several fields. They represent as many as 46 professions or occupations. Among them, about 53 per cent of them are in IT fields and about 10.8 per cent are teachers. Housewives 5.8 per cent; Business people 3 per cent; Self-employed 5.3 per cent; Researchers 2 per cent; and Scientists 1.9 per cent. Self-employed, housewives, business people and students account for 18 per cent of them. The rest of them (18.7 per cent) are in other professions or occupations (Figure 1). 


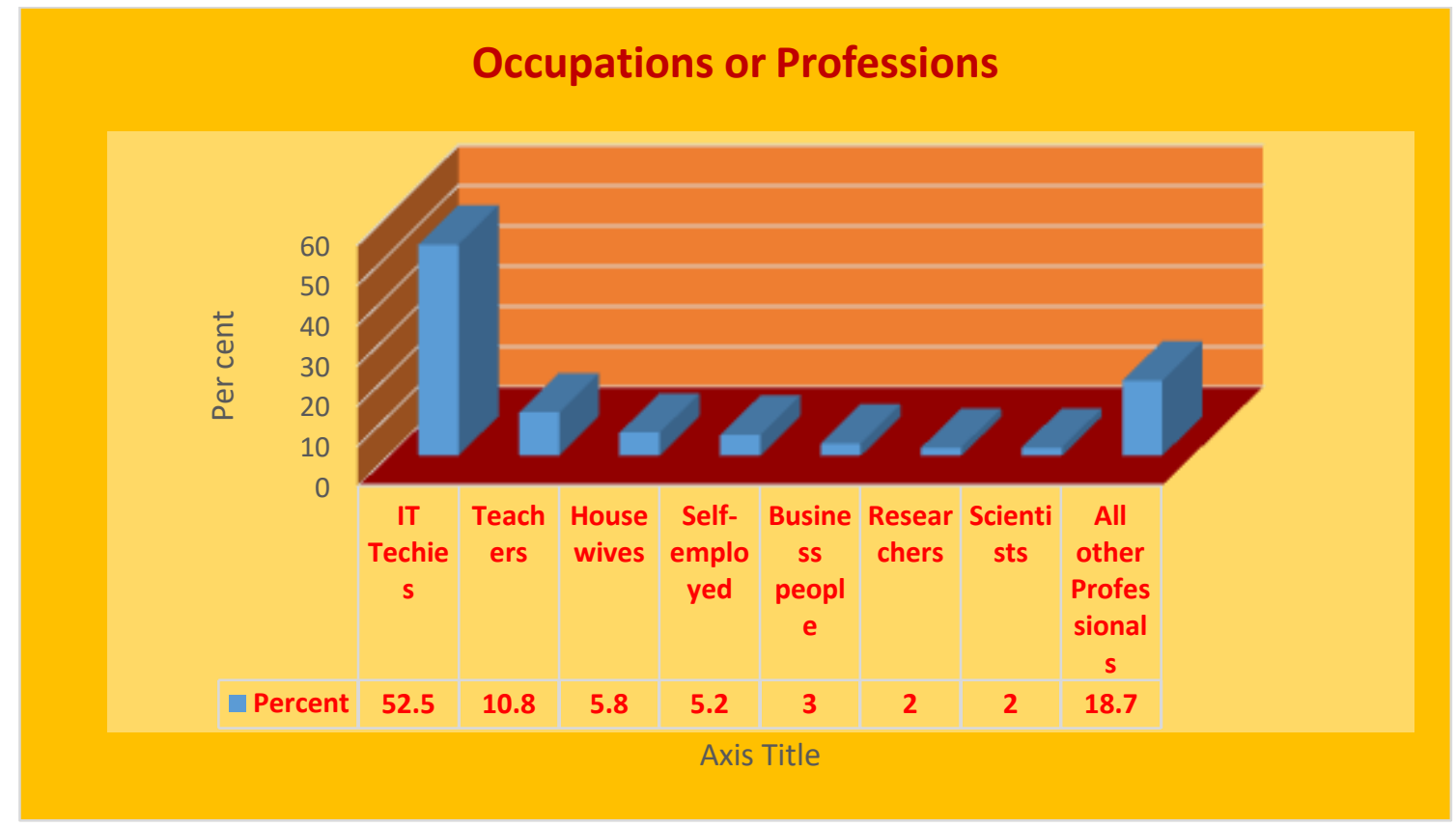

Figure 1

Home as a Safe Zone. A good majority of 51.7 per cent of the survey participants feels that their homes are very much a safe zone. And it is much so for 39.2 per cent of the households as well. Only 9.1 per cent of the survey participants feel that their homes are not at all safe zones.

At Work from Home during Lockdown. Nearly a fifth of the people (19.7 per cent) are not at work-from-home while an exact fourth of them are much at work-from-home and 55.3 per cent of them very much so. This means that 80.3 per cent of them are working from home for the last two months (Figure 2, Plate $1)$.

I was/am at work from home

208 responses

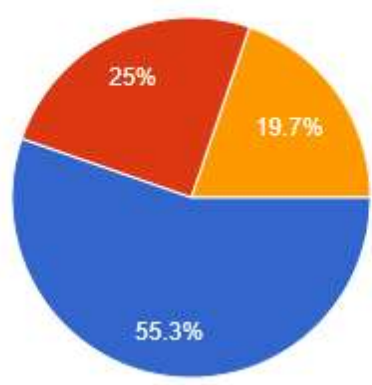

Very much

- Much

Not at all

Figure 2 


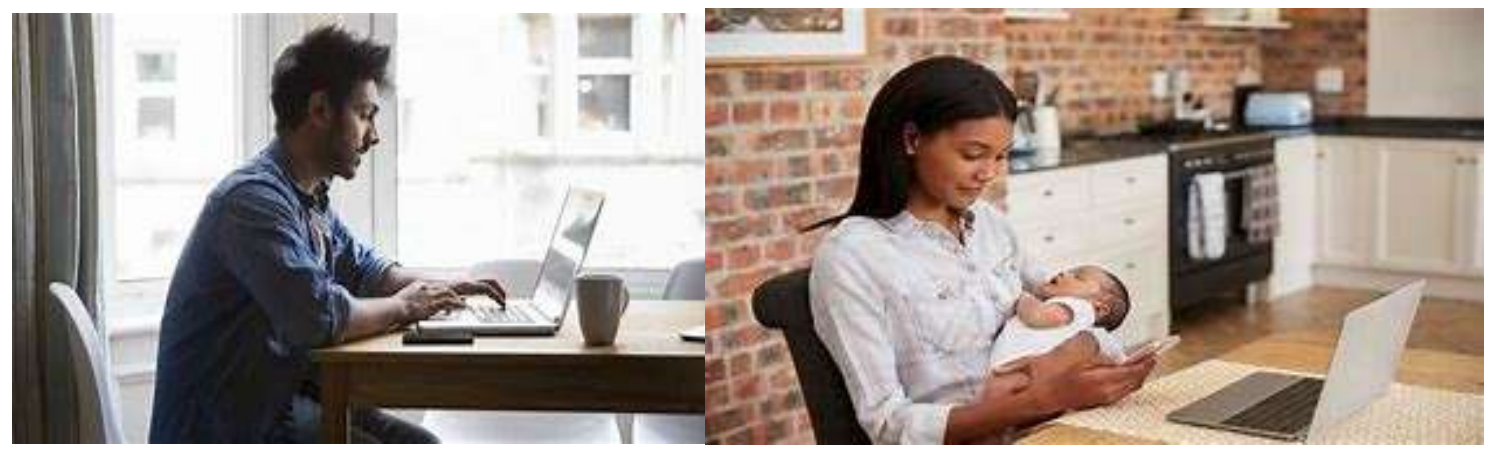

Plate 1. IT People working from home

Population density of the area of the Survey Participants. Whereas 30.2 per cent of them are in localities with high population, 60.5 per cent of them are in moderately populated areas, with 9.3 per cent of them living in low population areas.

Travel History. As for travel history before lockdown, 46.5 per cent of the respondents have had interstate (11.2 per cent), international (4 3 per cent), within the city (25.2 per cent) and intrastate (5.8 per cent) travel experiences. Those with international travel history are all however men. Only a few women (2.7 per cent) have travelled interstate (Plate 2). A good number of women (22 per cent) and an equally good number of men (23.7 per cent) have had no travel history at all (45.7 per cent of them).

Corona Cases in the Locality of the Survey Participants. As much as 40.6 per cent of the people have shown the presence of coronavirus in their localities and the rest (59.4 per cent) have indicated no such infections about them (Figure 3 , Plate 3). 


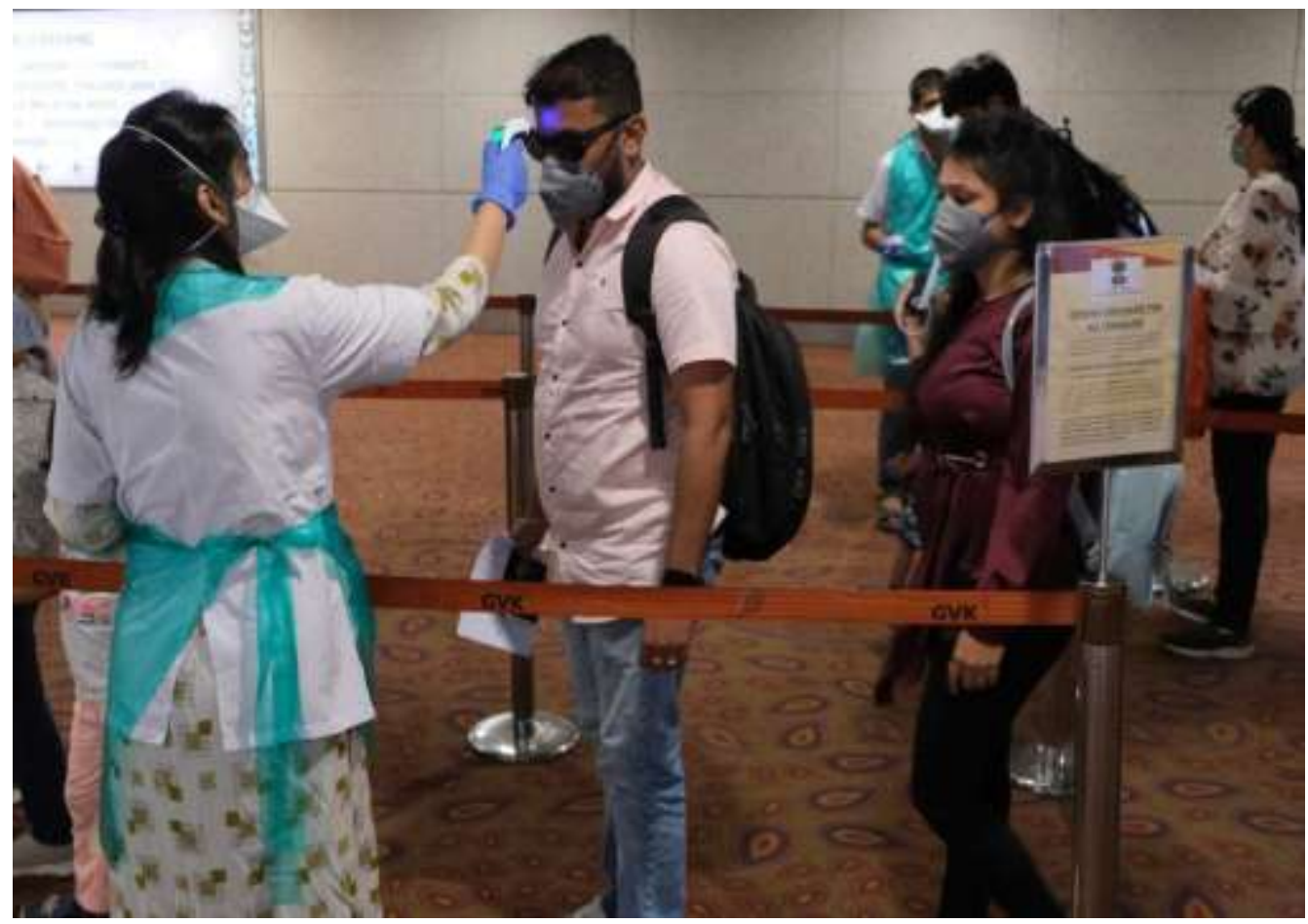

Plate 2. Returnees from abroad (Chennai airport)

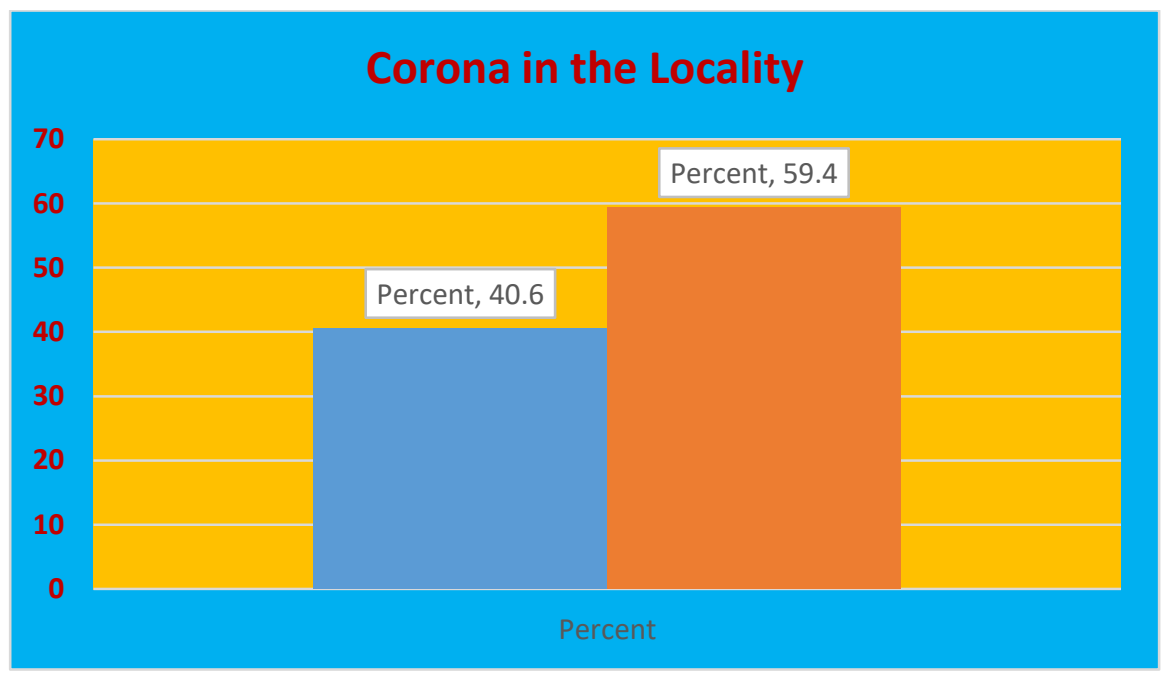

Figure 3

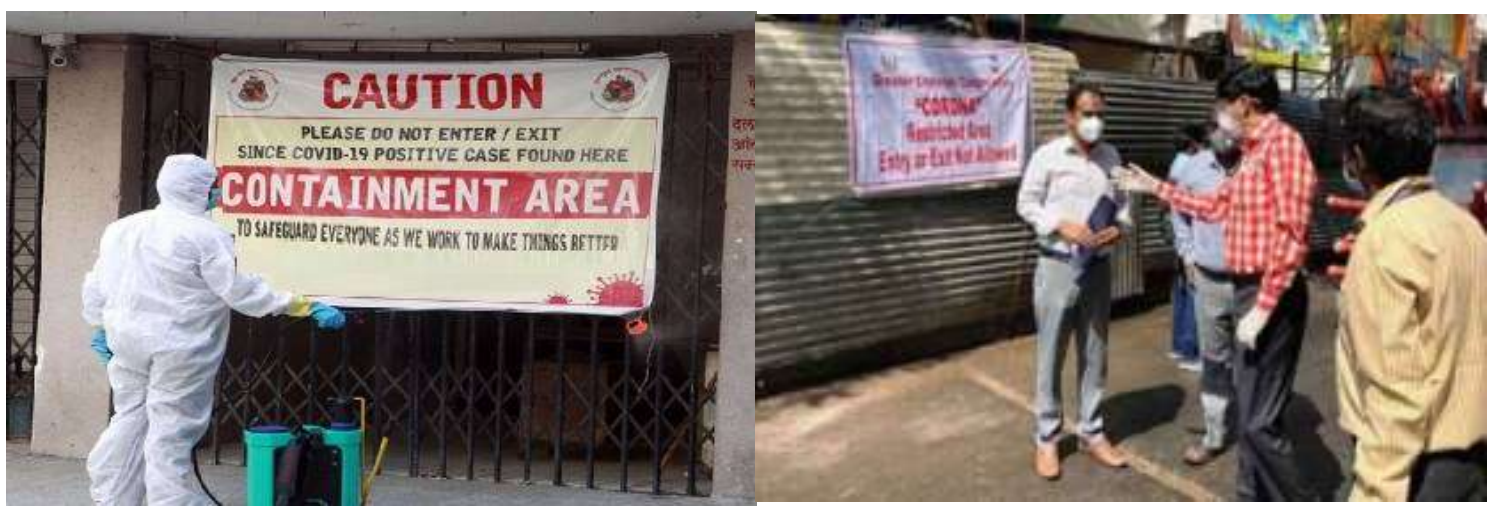


Plate 3. A containment area in Chennai (left) and health officials at the area.

Coronavirus Symptoms at home. Among the survey participant households, no symptoms have been displayed by 96.6 per cent of the households. The rest of them however have shown symptoms such as headache (3.4 per cent), cough (2.4 per cent), and fever (1.0 per cent).

Knowledge and Understanding of Seriousness of the Pandemic. About 63 per cent of the people/participants of the survey have said that they have understood the seriousness of the pandemic very much (strongly agree). This includes about 26 per cent of the participants who are women. About 32 per cent of them have understood the seriousness much (agree) and among them are women constituting just about 10 per cent. Very small proportions of them (6 per cent) have however had the minimum levels of understanding of the seriousness, by their admission (Figure 4).

I knew/know and understood/understand the seriousness of corona pandemic 209 responses

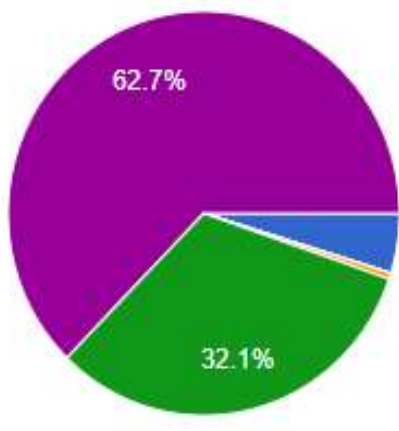

Figure 4

Disturbance from the Coronavirus. Except for one, all other survey participants have reported being disturbed by the Coronavirus pandemic. About 20 per cent of them are very much disturbed, 37.3 per cent of them much disturbed, nearly 27 per cent of them are not worried/disturbed at all and about 16 per cent of them have various levels of disturbance, and of these 10.5 per cent have very low levels of disturbance (Figure 5).

Preference for Complete Lockdown. As many as 90 big cities in India are under lockdown and they have shown a great decline in air pollution because no vehicles were plying for almost 8 weeks. 
I was/am disturbed by COVID-19

209 responses

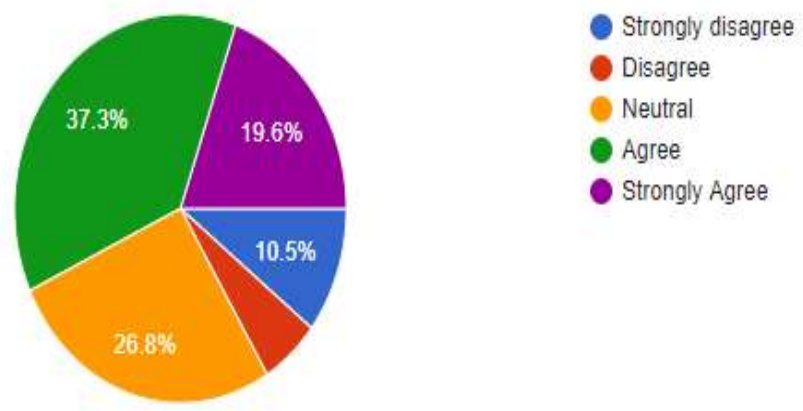

Figure 5

A majority of about 54 per cent of the survey participants is very much for a complete lockdown, about 39 per cent of them prefer it much (see Plate 4); and only about 8 per cent have shown no preference for the same.
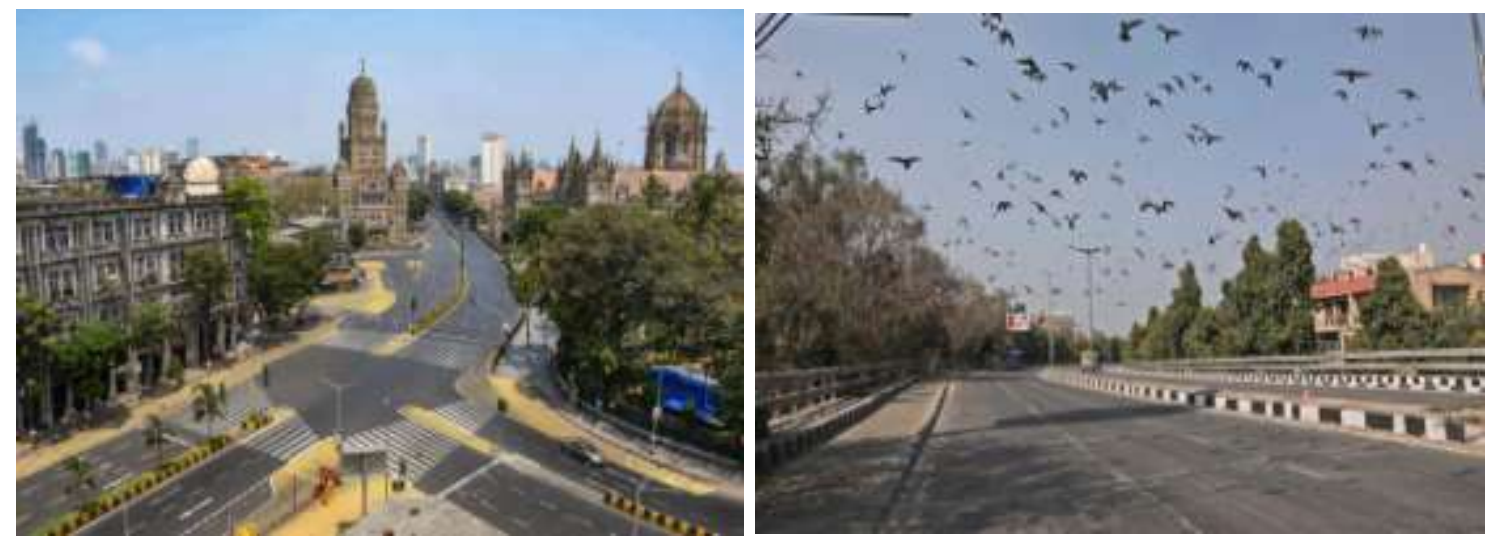

Plate 4. Chennai city at complete lockdown April 2020.

Feeling Left Alone under Lockdown. The lockdown has affected the homebound differently as slightly less than two-thirds of the people do not at all feel left alone under lockdown (65.6 per cent) whereas 8.6 per cent is very much affected while 25.8 per cent of them much affected.

The family has Psychological Trauma. Fortunately, however, 74.2 per cent of all the survey participants do not report psychological trauma in their families. About 8 per cent of them are frightened of the prospects, 9.6 per cent of them are disturbed in their sleep or cannot sleep at all, and 9.1per cent of people are not taking timely food. While 6.7 per cent of the people are feeling withdrawn, 2.9 per cent of them are feeling withdrawn as well as have nightmares in their 
sleep. Some of them are not interacting with their family members (2.9 per cent) and the rest of them have a combination of several disturbing and also traumatic experiences.

Family Members Vulnerable. There are aged, elderly people at the homes of 28.5 per cent of the survey-participant households. Also, there are people with diabetes in 13.9 per cent of their homes. People with hypertension accounts for 2.4 per cent of the survey-participant households. As such nearly 55 per cent of the respondent households have vulnerable family members with them.

Experiencing Health Challenges. Many of the people working from home, and their spouses and children, faced a variety of health challenges during the lockdown. Of the ten such challenges reported by them, disturbed sleep accounts for 35.6 per cent, back pain 28.2 per cent, poor appetite 10.2 per cent, headache 11.3 per cent, body pain 11.3 per cent and fatigue 11.9 per cent (Figure 6). All others are reported by a very small number of people. A good number of people (12.4 per cent) however indicate no challenges whatsoever.

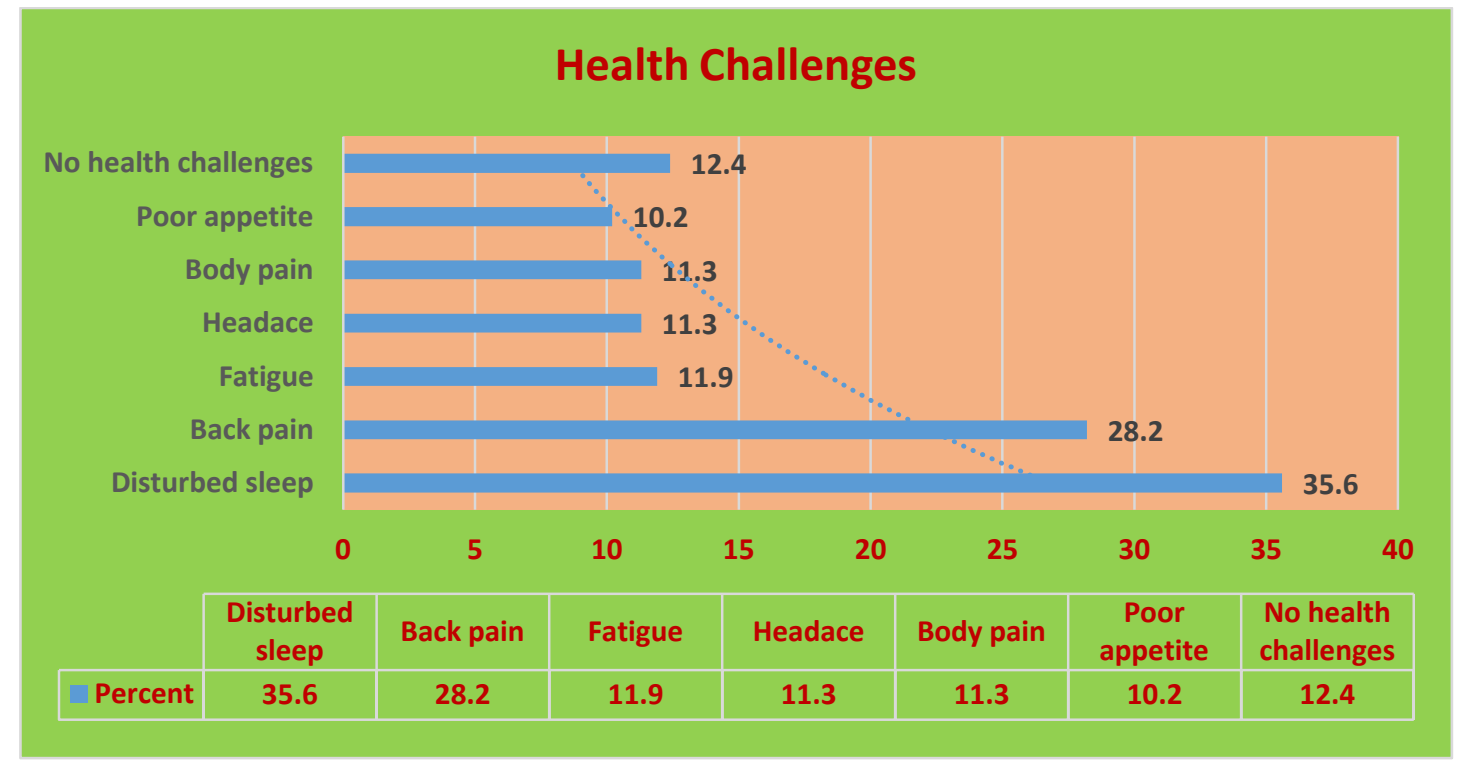

Figure 6

Public Health Officials Visiting Home. Only 35.6 per cent of the survey participants have reported about the visit of public health officials to their homes during the lockdown period. As much as 64.4 per cent of them have indicated no visits from public health officials (Plate 5).

Overcoming Boredom and Lethargy. To overcome boredom and lethargy during the lockdown, the people working from home. and also those who are not, have been engaged in more than 50 different activities. More than Two- 
thirds (69.2 per cent) of the survey participants have been working from home, diligently as well as effectively.
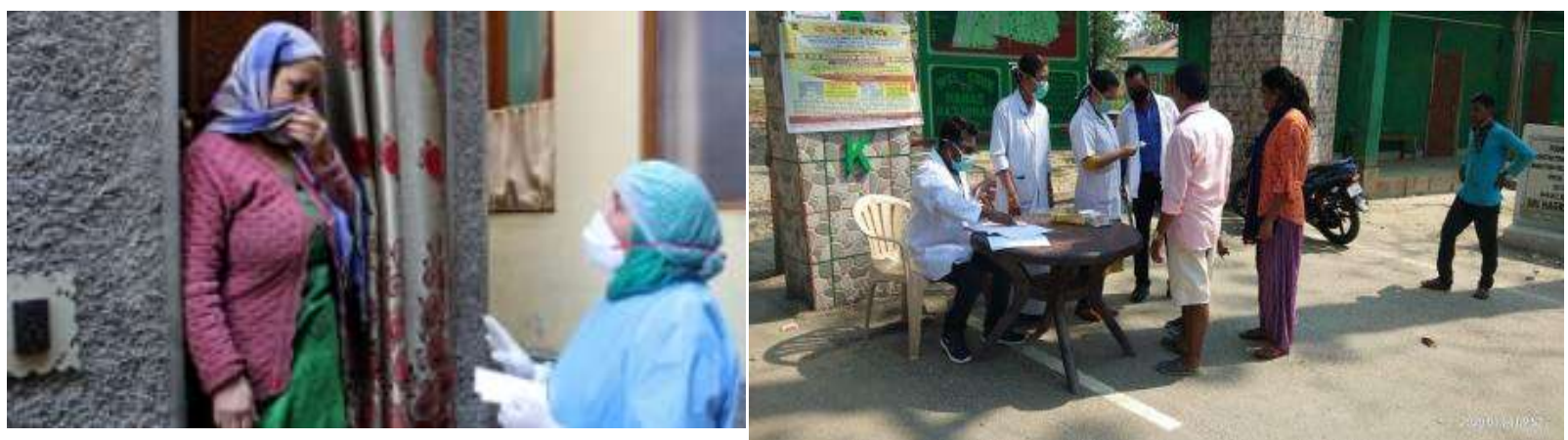

Plate 5. Health officials visiting households (left) and health checks at a containment area in Greater Chennai Corporation April 2020.

The most important activity in which a majority of 58.7 per cent has been engaged is that of watching movies, followed closely at 48.6 per cent in playing with children and at 48.1 per cent in listening to music. An equally good number of people (45.7 per cent) have been engaged in telephonic chat with friends to overcome boredom and lethargy (Figure 7).

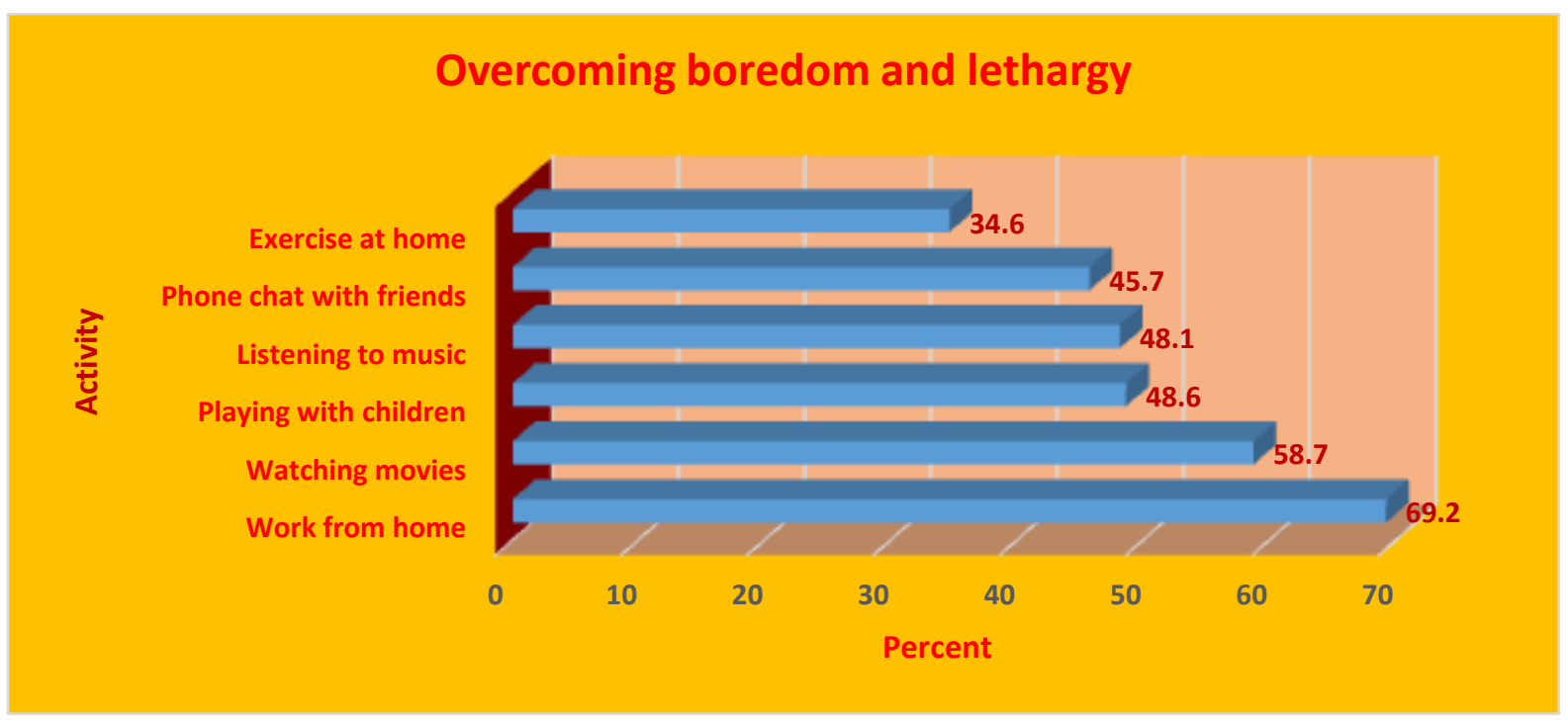

Figure 7

Exercising at home (34.6 per cent), reading books (2.7 per cent), gardening (1.3 per cent) are the other important activities to kill boredom and extricate lethargy. Many of the other activities have been carried on by a very tiny proportion of the people.

Exercising at Home. People at home do as many as 22 different and good exercises to keep themselves fit. Generally, however, they practice a combination of exercises, according to their ages and interests, which can be 
easily performed within the confines of their homes, as they have restrictions on their movements outdoors.

For several of them, the fear of the coronavirus infection keeps them indoors. Walking (61 per cent), yoga (27 per cent), meditation (25 per cent), cycling (6.5 per cent), treadmill (4 per cent), weightlifting ( 4.5 per cent) and a host of others (with small proportions) are the physical activities and exercises performed to keep fit under lockdown (Figure 8).

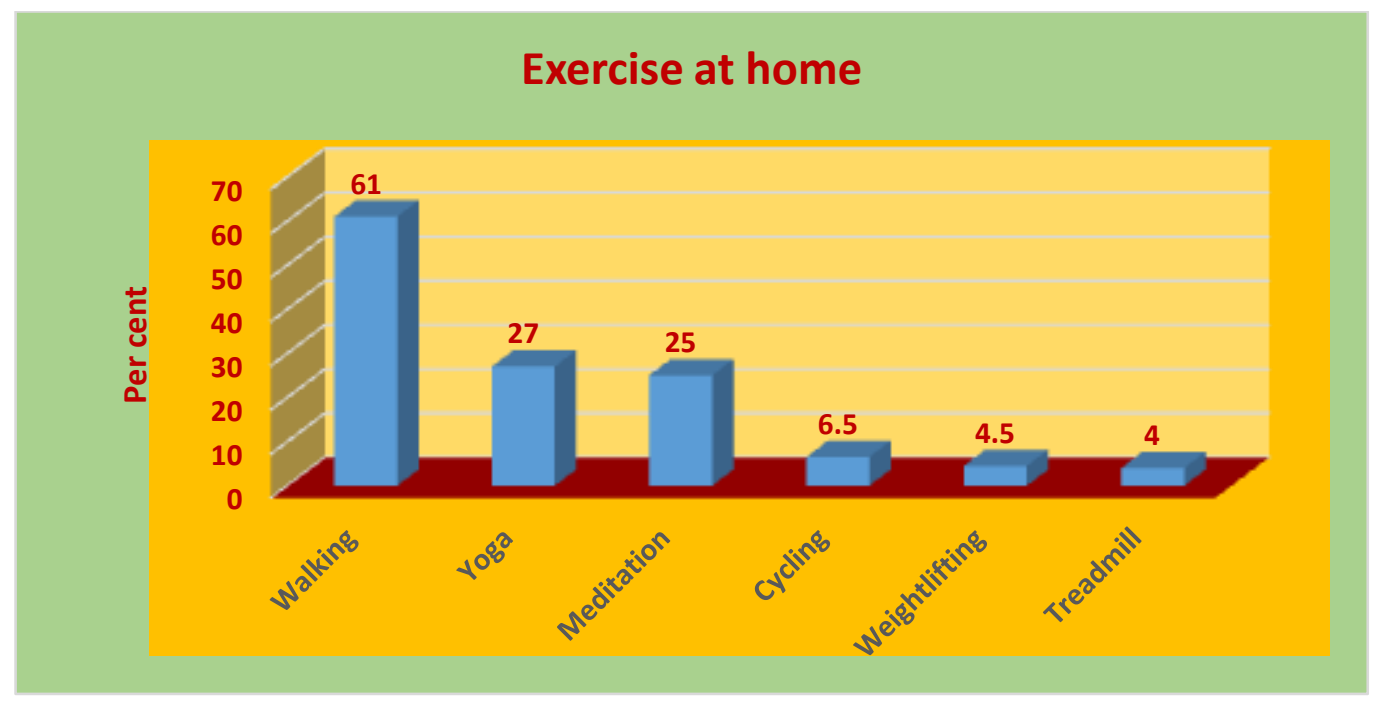

Figure 8

Walking is the most common form of exercise performed, in combination with several other physical exercises to keep oneself fit.

Spent Quality Time with Family. The lockdown has been such that the survey participants have had some very good, quality time with their families.

62.3 per cent of them have spent quality time with their families very much while 31.9 per cent of them have spent quality time with their families (Plate 6). Only 5.8 per cent of them report that they have not spent quality time with their families, for some reasons. Maybe they have been away from their families, elsewhere, caught up in the lockdown that they have not been able to be with their families. 


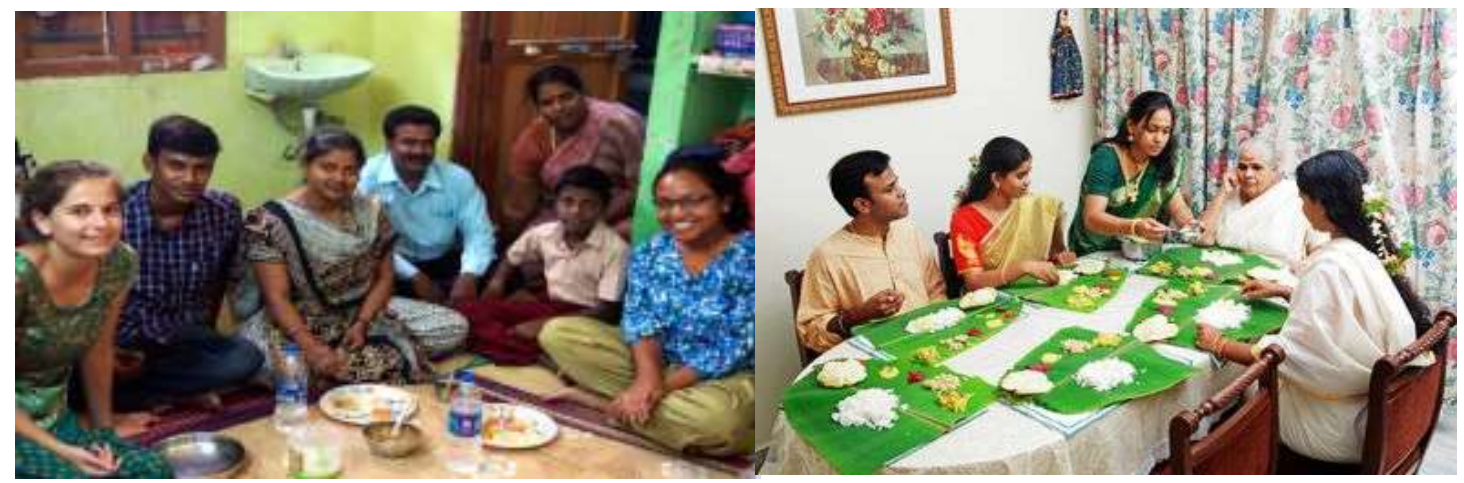

Plate 6. People happily spending their time together at home under lockdown.

Nutritious Food at Home during Lockdown. The food consumption at home by 45.9 per cent is very much nutritious and healthy, but a majority of 51.2 per cent of the survey participants have reported their food as being much nutritious.

A small proportion of people (2.9 per cent) however has shown that their food has not at all been nutritious, for either they cannot afford it or they have no access to such.

Going Out for Home Needs. During the entire lockdown, the essential commodities for homes have been made available through retail outlets. There have been reports of panic buying of essentials, nevertheless. Most households (55.3 per cent) have however made purchases once a week. About 19.7 per cent of the households have made purchases twice a week while 8.7 per cent of them daily (Plate 7).

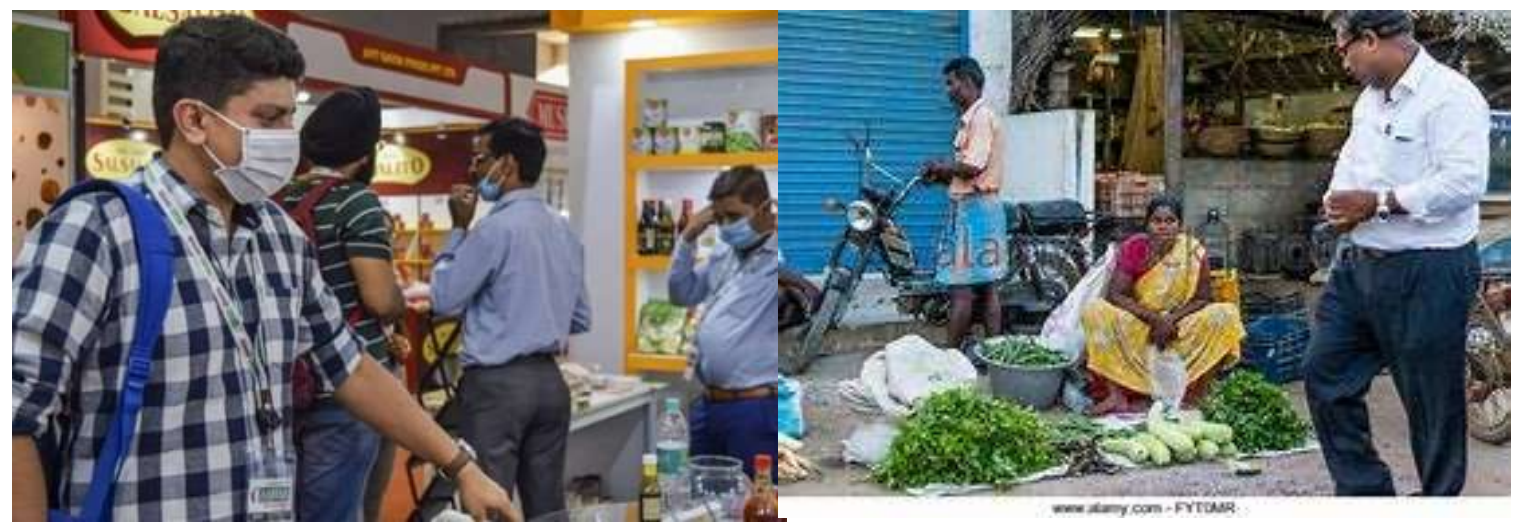

Plate 7. People buying up essentials for the home during the lockdown.

About 16 per cent of the survey participant households have never made any purchases and as such have never gone out of their homes for home needs. Some of course have bought their essentials from street vendors or itinerary traders with push-carts. 
Experiencing Financial Strain and Loss. One of the major problems wrought by the lockdown, and its announcement without giving time to get ready for it, has been the financial strains for the people who are at home, whether or not working from home.

Most have faced a loss of jobs, income, quick depletion of savings, half salaries/wages and such hardships. But 37.5 per cent of our survey participants have reported financial strains and loss and the rest (62.5 per cent) no such strains.

Changed Sleeping Patterns. For a majority of 52.9 per cent of the survey participants, there has been no perceptible change in their sleeping patterns. For a little more than a fourth of them (25.7 per cent), there has been an increase in sleeping patterns. For about 21.4 per cent of them, however, there has been a decrease in sleep.

Overcoming Coronavirus Pandemic. Those who work from home, and also those who are under self-quarantine at home, are sure of the strategies that could help them over coronavirus. A large majority of them (86.9 per cent) think that increasing immunity and staying positive could greatly help; 83 per cent of them think that staying home and staying safe could help as well; 78.6 per cent say that following government guidelines could help; 77.7 per cent suggest never to go out unnecessarily for overcoming the pandemic and 75.2 per cent opt for wearing a face mask when going out for overcoming coronavirus (see Plate 8).

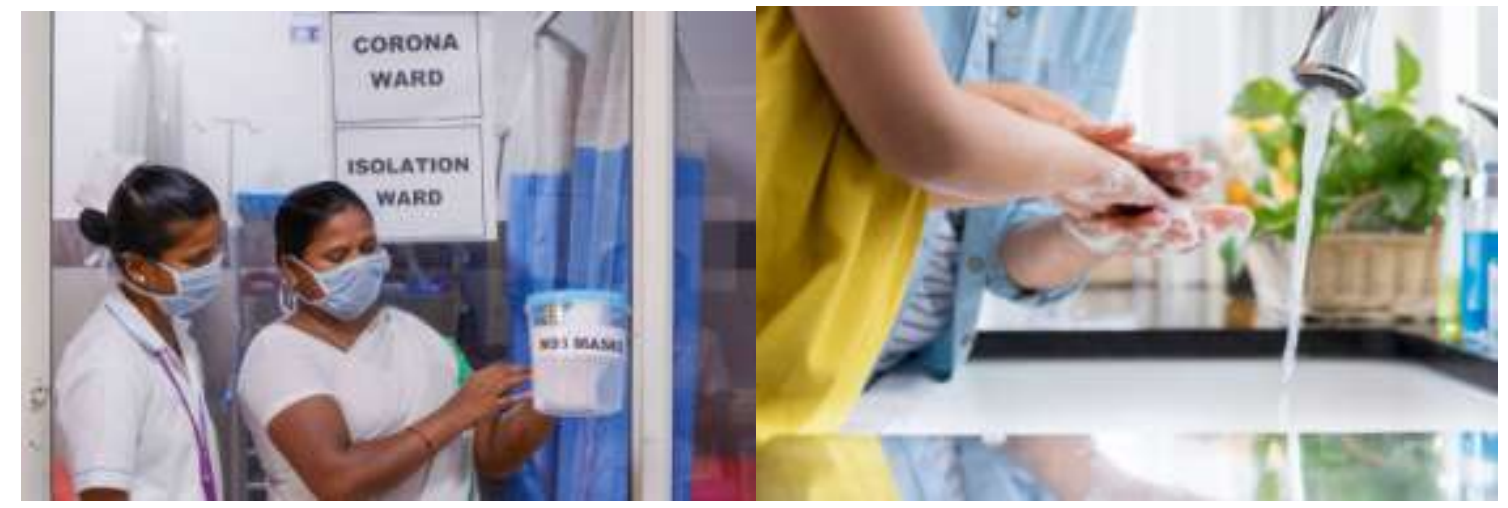

Plate 8. Seeking help at hospitals/isolation wards and keeping personal hygiene as means of overcoming the pandemic.

Precautions Taken at Home. Asked as to what precautions the survey participants have indicated some very good precautions. A majority of 60.6 per cent of them have taken care to periodically wash their hands. In 42.3 per cent of their households, daily floor cleaning with disinfectant has been done. In a 
little more than a fifth of their families (19.2 per cent), they have maintained social distance even while eating.

More than a tenth of them (10.6 per cent) have indicated that they have slept in separate rooms. About 35 per cent of the respondents have said that they have followed all the above. But a little less than a tenth of them (9.6 per cent) have followed none of the above.

Taking Immune Boosting Medications. Asked about what immune-boosting medicines they have taken, the survey respondents have indicated the systems of medicines rather than the medicines themselves. As low as 6 per cent of them have taken to Ayurveda; 6 per cent have taken Siddha medicines; 2 per cent each have taken allopathic medicines and homoeopathy medicines. A whopping 53.7 per cent of them have eaten foods with lots of vitamins and minerals. Also, 4 per cent of them have taken all the above. But as much as 26.2 per cent of them have taken none of the above.

Precautions Taken While Out on Shopping for Essentials. Asked further as to what precautions they have taken while shopping for essentials, 67.8 per cent of them have washed them with warm water while 20 per cent of them have dried them in the sun. About 11 per cent have done nothing of the sort.

Caring for Senior Citizens at Home. Appropriate care of the seniors at home has been reported from most households of the survey participants. Timely medication as per physician's directions (30.2 per cent) and engaging them with more interactions at home (28.1 per cent) together account for 58.3 per cent of the households.

Besides that, 21.4 per cent of the households have assured enough sleep for the elderly at home. More than a fourth of the households (27.1 per cent) have practised all of the above but nearly 28 per cent of them none of the above.

Helping Spouse and Mother in the Kitchen. Those who work from home, and those who are at home under lockdown, help with the kitchen and household chores (Plate 9). Particularly spouses (husbands/wives), mostly men, help with buying essentials and vegetables at the market (36 per cent), vegetable cutting (27.4 per cent), dishwashing ( 28.4 per cent), meals preparations ( 24.9 per cent) and serving food to the family (28.4 per cent). 


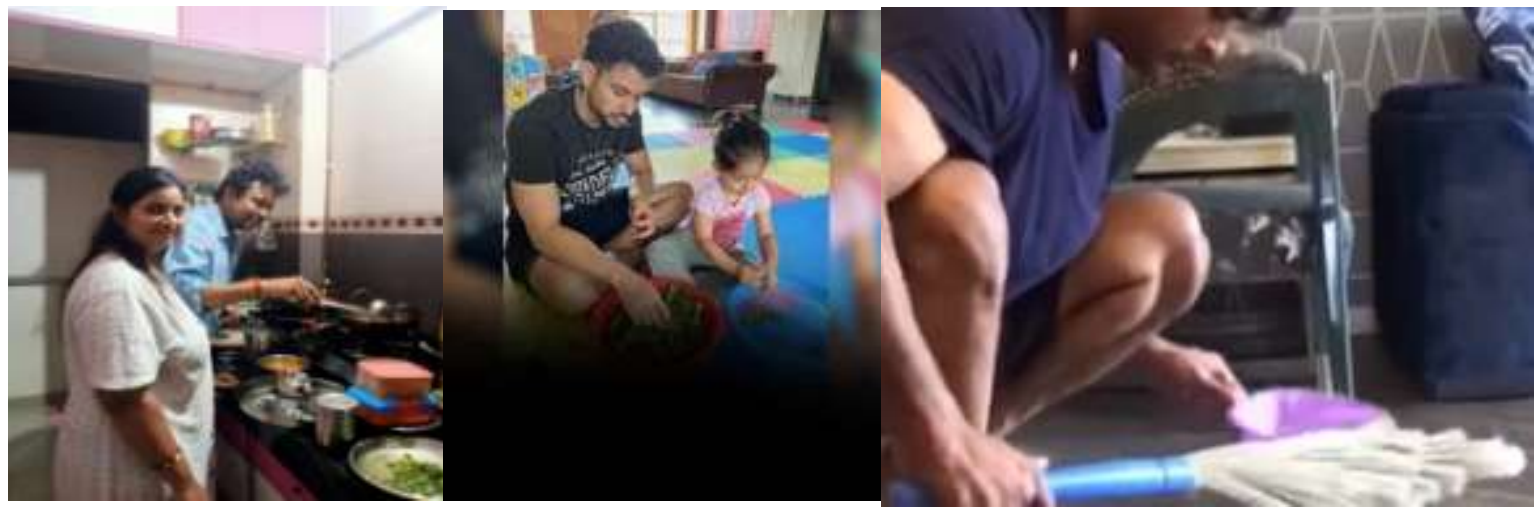

Plate 9. Spouses (wife/husband) help in the kitchen and household chores.

Some of them do help their mothers with household chores as well as kitchen chores. Overall, 42.6 per cent of them do all the above. Only 8.6 per cent of them do not do any of the above.

Managing Children during Lockdown. The households of those under lockdown and at home, working or otherwise, are engaged in managing the children the best way they can. While 48 per cent of them helping them to engage in online learning, even as 34.9 per cent of them help them with learning artwork. Men and women of a whopping 71.5 per cent of the families chat/speak with their children even as 39 per cent of the households play games with their children (Figure 9).

A good proportion of them (18.6 per cent) are engaged in teaching the children scriptures / slogas and 39 per cent of them play mind games with them (puzzles and riddles). About 3 per cent of them do none of these either because they are otherwise engaged or have no children at home (Plate 10).

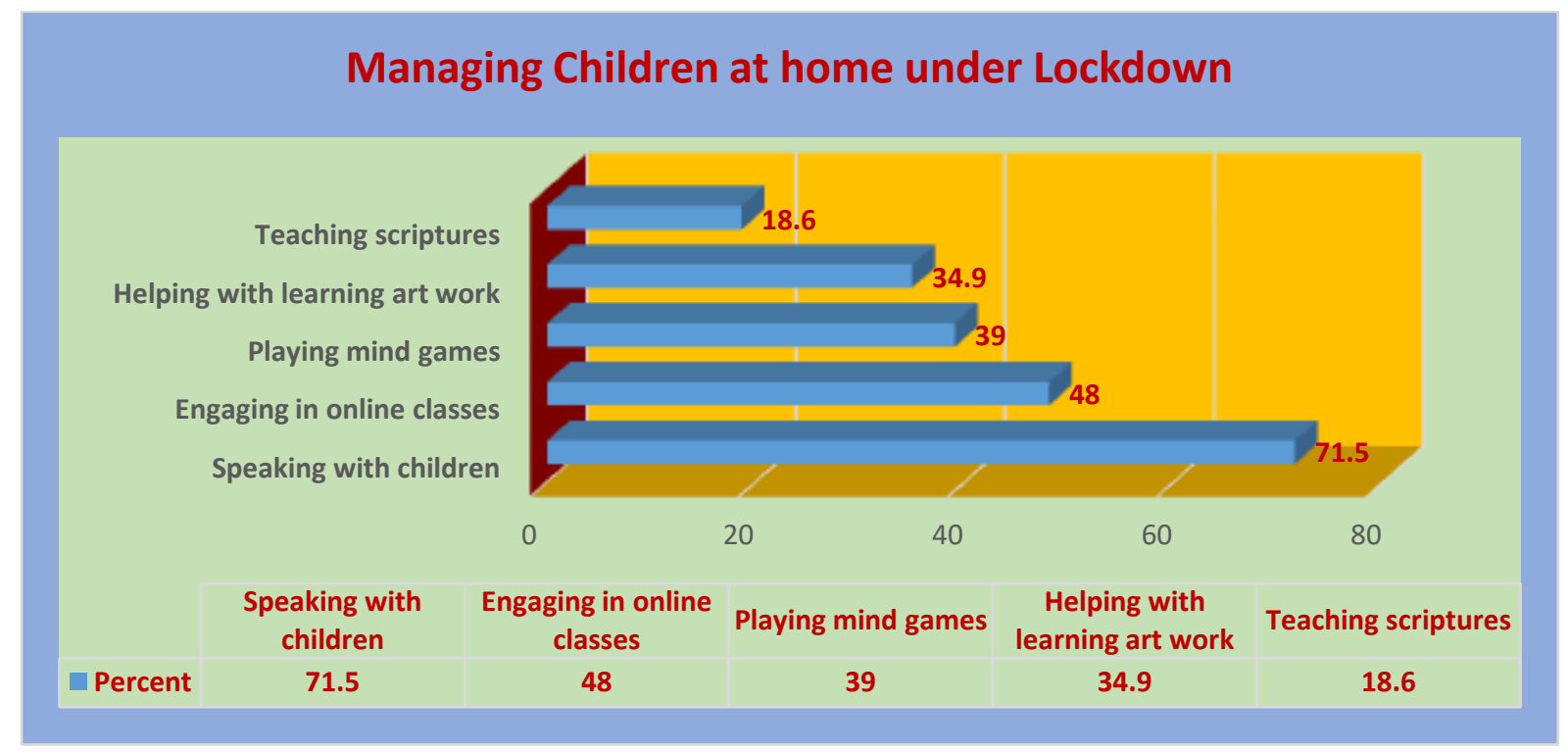

Figure 9 

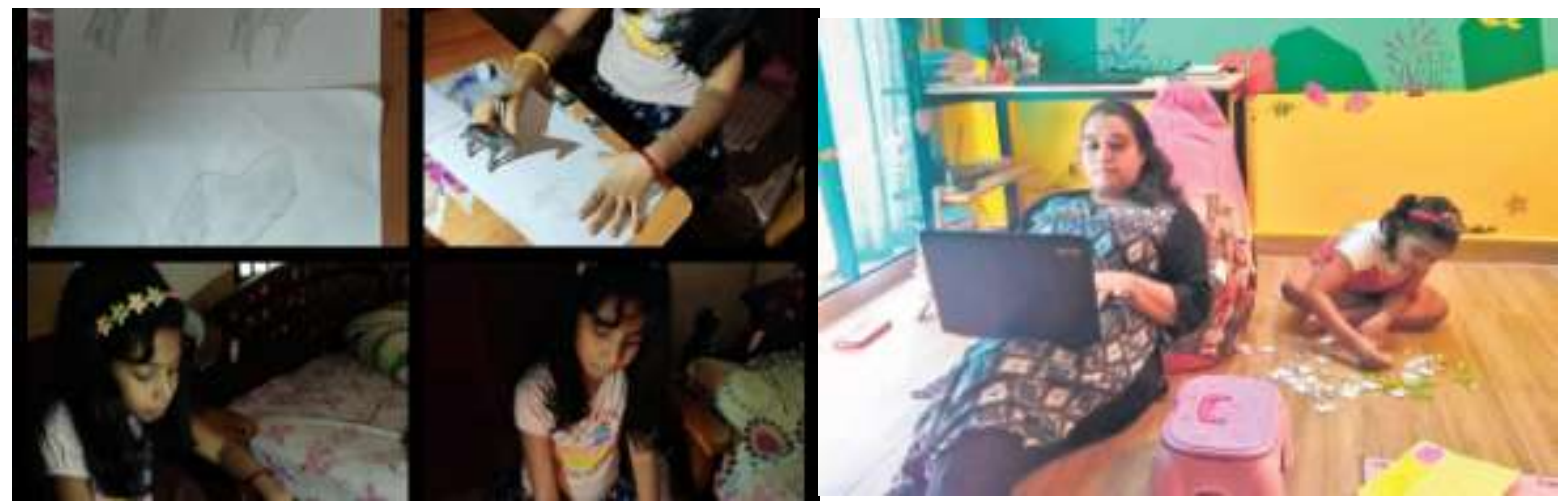

Plate 10. Managing children at home with various activities for the lockdown.

Women Coping with Lockdown. Women of India have shown enormous grit during the lockdown and have better managed their home and work than probable men. Nearly two-thirds of them (65.4 per cent) have spent time with their families, 30.1 per cent of them have been engaged in their chosen area of work, at home (Figure 10).

They have also been able to assign tasks appropriate to age (18.4 per cent) for their children, spouses or elderly at home. As much as 49.3 per cent of them have spent their time learning new recipes. About 31 per cent of them have been engaged in their hobbies.

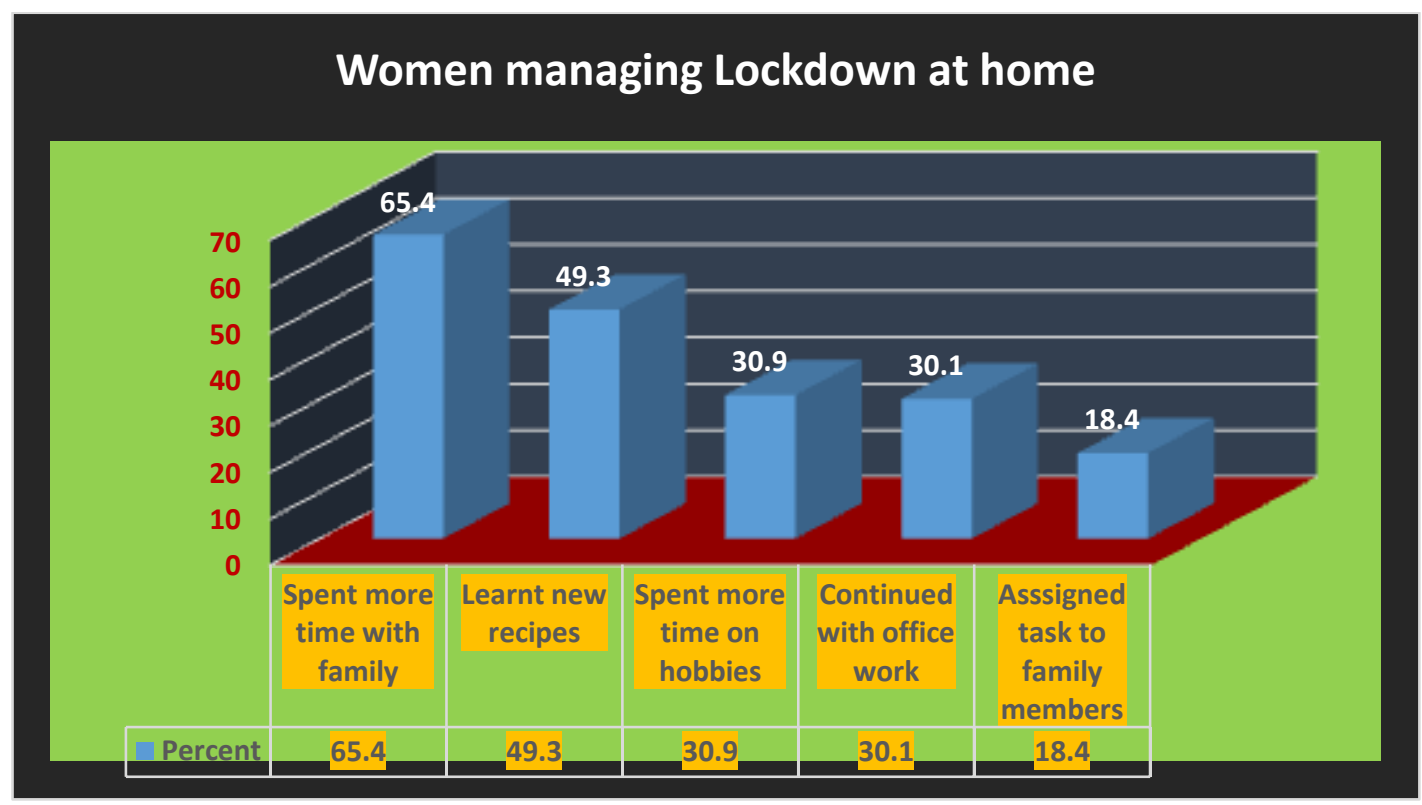

Figure 10

Mental Stress due to Coronavirus. A study has indicated that 61 per cent of the Indians have experienced mental stress during the lockdown. Our study indicates that the survey participants preferred staying positive (78.5 per cent), spending more time with the family ( 57.5 per cent), recollecting the best times 
of life ( 40 per cent), regularly exercising to boost the immune systems ( 40.5 per cent) and of course learn new things (a poor 0.5 per cent).

Mentally Prepared for Extended Lockdown. Asked as to whether the survey participants are mentally prepared for an extended lockdown, and what they would do to get ready for an extended lockdown, they have the following to say: Except for a small proportion of them who think that the lockdown is a waste (nearly 4 per cent), all others speak of what they would in such an eventuality: will keep sufficient stock of home needs 21.3 per cent, keep enough money for medicare 48.7 per cent, help the needy in the neighbourhood 43 per cent, take a week off for work from home 61 per cent, get psychological counselling to overcome stress 2 per cent and volunteer for charity work 20.8 per cent.

Helping a Relative or Friend who Tested Positive. Asked about how they could help a relative or a friend who has tested positive for coronavirus infection, the survey participants have given their several responses but the most important ones are: Extending full support and expenses 2.4 per cent, prayers for speedy recovery 47.2 per cent, keeping his/her family members in positive spirit 47.2 per cent and limiting visits to them 1.4 per cent. Overall, all the above account for 32.9 per cent.

Measures Taken if Having Comorbidities. Asked as to what measures they have taken to help coronavirus infected people with comorbidities such as diabetes and hypertension, the survey participants have indicated the following: making sure of daily exercise 33.9 per cent, regular medication 30 per cent, timely food with the right salt and sugar 41 per cent, and mind relaxing activities 48.9 per cent. Overall, 28 per cent of them have used all the above.

Precautions Needed to Overcome Similar Scenario in Future. Finally, the survey respondents have been asked to give their thinking on the precautions needed to overcome similar scenario in the future.

They have given several views on the precautions needed and they are self-discipline 49.8 per cent, the discovery of a vaccine 42.3 per cent, early detection of the virus or disease 42.8 per cent, social distancing 41.5 per cent, transparent reporting 36.7 per cent, protecting the biodiversity of the planet 25.4 per cent, international cooperation for sustainable human living 26.9 per cent, and last not the least being positive 25.4 per cent (Plates 11 and 12). 


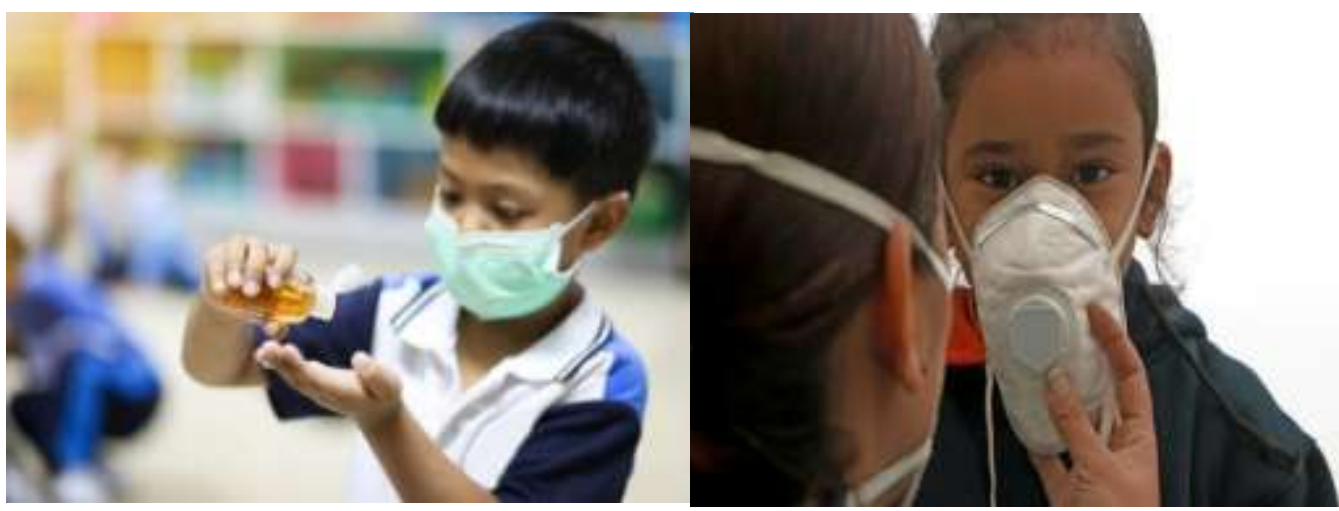

Plate 12. Precautions necessary to overcome a similar scenario in future.

Overall, more than half the participants (51.7 per cent) have indicated all of the above.

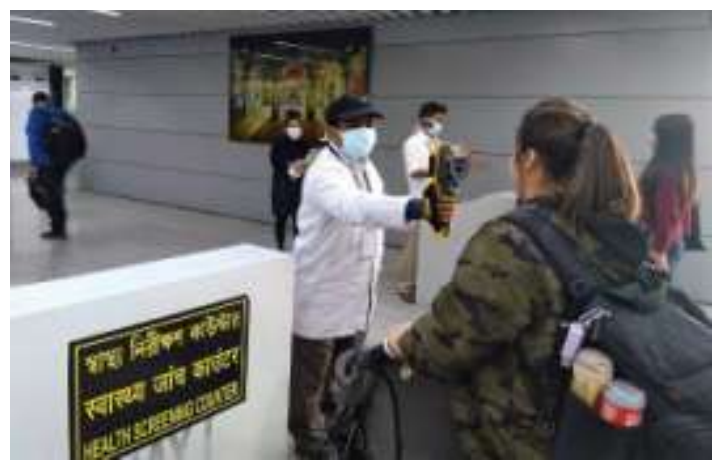

Plate 12. Health screening counter at the airports.

\section{Conclusion}

The study has brought to light how the people have managed their stay home in the past two and a half months (March-June 2020) under lockdown, from lockdown 1.0 to lockdown 4.0. A cross-section of professionals and workers in 46 different fields of the economy has shown that the lockdown has been very hard on them, resulting in some of them losing their livelihoods, income and even jobs. It has been very depressing for the small scale industry operators, interior designers, temple priests, educationists, teachers and servant maids. Educationists and teachers have however been redeemed in a way they could take on online classes and blended teaching such that they stay engaged with their work and teaching. The plight of servant maids is perhaps the worst ever.

The online survey, using Google Forms and WhatsApp, has been successful in that it has brought out the various aspects of social behaviours of the people under lockdown. Two hundred and ten people of all ages, 21-66 years, with about 69 per cent men and about 31 per cent women, and about 87 per cent Indians and about 13 per cent NRIs abroad, have indicated their 
positive as well as negative experiences during the lockdown necessitated by the coronavirus pandemic. Professionals of 46 different sectors of the economy, with four-fifths of them working from home, a very large majority of them (90.9 per cent of them) have spoken of home as a safe zone.

Yet, with three-fifths of them clearly understanding the seriousness of the situation and the pandemic crisis, about 57 per cent of them have been disturbed by the pandemic, they have felt that they have been burdened by work in the confines of their homes, feeling lonely (34.4 per cent) under lockdown and also stressed because their family has people with psychological trauma (26 per cent), elderly with health concerns (in 28.5 per cent of their households), experiencing financial strains and loss (37.5 per cent of them), and yet, in a salutary fashion, spending quality time with family and children (62.3 per cent). They have experienced troubled sleeping patterns ( 47 per cent) but have taken necessary and appropriate precautions for overcoming the virus (about 90 per cent), taking immune-boosting foods (97 per cent), and taking care of the elderly (72 per cent).

But the mixed situation at home and outdoors has caused considerable behavioural changes and adjustments in their lives and deeds. Everyone has been worried, even afraid under the pandemic threat but managed well nevertheless. The pandemic has indeed been a black swan event, bringing chaos and catastrophe in many a home. The study has also made clear that 'the way we live our lives has changed.' In all of these, saving lives has been more important.

\section{References}

1. Honey-Roses, J., Anguelovski, I., Bohigas, J., Chireh, V., Daher, C., Konijnendijk, C., ... Nieuwenhuijsen, M. 2020 (April 21). The impact of COVID-19 on public space: A review of the emerging questions. https://doi.org/10.31219/osf.io/rf7xa.

2. Jebaraj, Priscilla (May 17) 2020. Reforms and agriculture. FAQ. The Hindu: 12.

3. Lakshman, Narayan (May 17) 2020. Commonwealth collaboration has never been more important. Interview: Patricia Scotland. The Hindu: 9.

4. Low, Setha and Smart, Alan 2020. Thoughts about public space during the Covid-19 pandemic. City \& Society. American Anthropological Association. DOI: 10.1111/ciso.12260.

5. Ramani, Srinivasan (May 17) 2020. Will migrants benefit from the Centre's measures? FAQ. The Hindu: 12. 
6. Sankar, Madhurika (May 20) 2020. A callous response. OPED. The Hindu: 7.

7. Sinha, Yashwant and Thakur, Atul K. (May 20) 2020. Flawed stimulus is justice denied. OPED. The Hindu: 7.

8. Srinivasan, Raghuvir (May 17) 2020. How will the COVID-19 relief for MSMEs help? FAQ. The Hindu: 12.

9. Taleb, Nassim N. 2007. The Black Swan: The impact of the highly improbable. UK: Allen Lane.

10.https://drive.google.com/file/d/1GAyzXZ2TzHkEFZZ-

h7if9zBgED1aap/view? usp=drivesdk (questionnaire in Google Forms) 